Article

\title{
Tax Arrears Versus Financial Ratios in Bankruptcy Prediction
}

\author{
Oliver Lukason * and Art Andresson
}

Faculty of Economics and Business Administration, University of Tartu, Liivi 4, 50409 Tartu, Estonia; art@taust.ee

* Correspondence: oliver.lukason@ut.ee

Received: 4 November 2019; Accepted: 7 December 2019; Published: 11 December 2019

check for updates

\begin{abstract}
This paper aims to compare the usefulness of tax arrears and financial ratios in bankruptcy prediction. The analysis is based on the whole population of Estonian bankrupted and survived SMEs from 2013 to 2017. Logistic regression and multilayer perceptron are used as the prediction methods. The results indicate that closer to bankruptcy, tax arrears' information yields a higher prediction accuracy than financial ratios. A combined model of tax arrears and financial ratios is more useful than the individual models. The results enable us to outline several theoretical and practical implications.
\end{abstract}

Keywords: bankruptcy prediction; tax arrears; payment defaults; financial ratios

\section{Introduction}

In the year 2018, half a century had passed from the foundational multivariate bankruptcy prediction study conducted by Altman (1968). During this time, hundreds of financial ratio-based prediction models have been published (see e.g., reviews by Ravi Kumar and Ravi 2007; Sun et al. 2014; Alaka et al. 2018). The area has especially flourished with the advances in artificial intelligence, and substantial amount of new tools are being introduced annually. Although high prediction accuracies have been achieved with financial ratios, due to several reasons, they can never be fully relied on in bankruptcy prediction.

The first set of reasons includes the availability and accuracy of financial reports. Financial reporting delays or non-submission of reports are fairly common in case of SMEs, especially for financially distressed firms (Clatworthy and Peel 2016; Luypaert et al. 2016). The latter is characteristic to Estonia as well (Lukason 2013; Lukason and Camacho-Miñano 2019). In addition, as annual reports of SMEs are usually non-audited, they are at a higher risk of including faulty information (Altman et al. 2010). Thus, the financial ratios needed for prediction might be incorrect or not available.

The other substantial reason concerns how capable financial ratios are in signaling future bankruptcy of firms. It is an established fact that a fair share of firms regardless of their age can follow a failure process, where (serious) financial problems or performance declines are not observable in the last financial report before bankruptcy (Lukason et al. 2016; Lukason and Laitinen 2019). In addition, a remarkable number of firms perform poorly, but will never fail, and therefore, cannot be distinguished from their bankrupting counterparts, leading to a Type II error in classification models (du Jardin 2017).

Because of these reasons, an ongoingly important research question is whether there is a substitute for financial ratios in bankruptcy prediction. Various attempts have been utilized in this area, for instance using information about corporate governance, business environment, past payment defaults, and audit resolution (Lussier 1995; Back 2005; Ciampi 2015; Liang et al. 2016; Iwanicz-Drozdowska et al. 2016; Munoz-Izquierdo et al. 2019; Ciampi et al. 2019). Such studies have concluded that variables other than financial ratios can be individually better predictors or can at least provide some incremental value, when applied with financial ratios. 
Relying on the aforementioned general motivation, this study aims to find out how accurately future bankruptcy can be predicted by using tax arrears information and whether the accuracy exceeds the level of a financial ratio-based model. In the following literature review section, we synthesize the past findings of failure (prediction) studies in order to lay a foundation for the follow-up empirical part of the paper. The literature review section is followed by a thorough explanation of our dataset, variables calculated, and methods used. Then, empirical results with relevant discussion are presented, succeeded by both theoretical and empirical implications. This is followed by a separate section about the study's limitations and the paper ends with conclusive remarks, while also including multiple novel research directions.

\section{Literature Review}

\subsection{Firm Failure Process Leading to Bankruptcy}

The general theoretical foundation for the choice of variables for bankruptcy prediction is firm failure process, i.e., a pathway to bankruptcy. A firm failure process depicts in a certain timeframe how managerial actions in certain environmental conditions lead to an outcome such as poor profitability or illiquidity of a firm (Crutzen and Caillie 2008; Ooghe and Prijcker 2008). The theoretical models of firm failure processes (e.g., Weitzel and Jonsson 1989; Crutzen and Caillie 2008; Amankwah-Amoah 2016) have broken the pathway to bankruptcy into multiple consecutive stages, and concluded that in the earlier stages, problems might not be signaled through financial reports, and thus, finally bankrupting firms might not be (well) distinguishable from poorly performing, but finally surviving firms. Therefore, empirical studies have concluded that in the longer time horizon, financial ratios are not accurate in bankruptcy prediction (du Jardin 2017) and variables other than financial ratios would be beneficial (Iwanicz-Drozdowska et al. 2016).

Recent studies have indicated that the pre-bankruptcy problems indicated through the values of financial ratios or failure risk might not be observable enough through the pre-bankruptcy annual reports of SMEs more than one year before bankruptcy is declared. For instance, Lukason and Laitinen (2019) showed that for 73\% of analyzed European SMEs, bankruptcy risk became over 50\% and known financial ratios obtained negative values only in the last annual report before bankruptcy. Still, the latter result was obtained when looking at the median values of respective variables, and thus, a fair share of firms might not witness any observable problems in the last financial report (see e.g., Lukason et al. 2016).

A practical issue when using information from annual reports is the delay in information disclosure. Multiple studies (e.g., Altman et al. 2010; Luypaert et al. 2016) have vividly pointed to the issue that firms in (high) failure risk tend to delay the presentation of negative information. In the worst scenario, this can mean not submitting the pre-bankruptcy annual report at all, while the delay of the annual report beyond a deadline set in law (e.g., in Estonia 6 months after the fiscal year) becomes more like a "rule" rather than an exception (Lukason 2013).

\subsection{Financial Ratios as Predictors of Bankruptcy}

A vast amount of studies exploiting financial ratios for bankruptcy prediction have been composed so far with largely varying results (see e.g., literature reviews by Dimitras et al. 1996; Ravi Kumar and Ravi 2007; Sun et al. 2014; Alaka et al. 2018). As the situation of bankruptcy points to either a shortage of cash (liquidity crisis) and/or liabilities exceeding assets (solidity crisis) (Uhrig-Homburg 2005), the theoretical explanations of which ratios could be useful rely on both of them. The cash flow-based explanation to predictors' choice originates from Beaver (1966) idea of firm as a reservoir of liquid assets, while a (negative) equity-based explanation is most vividly explained in the probabilistic theory of bankruptcy developed by Scott (1981). Still, since the earlier multivariate contributions (e.g., Altman 1968; Ohlson 1980), the financial ratios for bankruptcy prediction have mostly been chosen on empirical grounds, without focusing on the mechanism leading to corporate collapse. The usual ratio domains 
applied in bankruptcy prediction, although occasionally phrased differently, concern liquidity, solidity, capital/financial structure, profitability, and turnover (Lukason et al. 2016; du Jardin 2017).

The recent cross-sectional studies using very large populations of European firms and t-1 period for bankruptcy prediction have indicated that areas under the curve (AUCs) remain on an average level, namely in the range of 0.7-0.9 and only on rare occasions exceed 0.9 (Laitinen and Suvas 2013; Altman et al. 2017). In a meta-analysis of bankruptcy prediction studies, du Jardin (2017) found the average $\mathrm{t}-1$ classification accuracy to be $85 \%$. Recently, studies have shown that prediction accuracies can be enhanced by accounting for the financial dynamics and patterns occurring before bankruptcy (e.g., du Jardin 2015, 2017, 2018), but still the misclassification rates have remained at $10-20 \%$. This provides a clear indication that financial ratios have inherent problems (see also Section 2.1), which cannot be overcome by using more sophisticated classification methods.

\subsection{Payment Defaults as Predictors of Bankruptcy}

A domain in the literature scantly developed is the usage of past payment defaults to predict bankruptcy. The few available studies (e.g., Laitinen 1999; Back 2005; Altman et al. 2010; Wilson and Altanlar 2014; Iwanicz-Drozdowska et al. 2016; Ciampi et al. 2019) have all indicated that past payment behavior can be valuable in bankruptcy prediction and lead to either higher classification accuracies individually or at least provide an increment to classification accuracies, when applied with financial ratios.

Despite substantial contribution to the area, the available studies have treated payment defaults in a rather simple way: by accounting their presence, number and size. Still, the extant studies do not pay attention to defaults in the longer time horizon, i.e., their exact dynamic behavior in respect to what pattern they follow. Another substantial issue in the portion of extant literature is that the applied payment defaults are permanent, namely they are a logical precedent to the future bankruptcy. Such application can lead to using de facto insolvency to predict de jure insolvency, reducing the practical applicability of such models, i.e., they do not lead to remarkable benefits for creditors aiming to reduce their misclassifications. Therefore, the practical usage of relevant prediction models can be enhanced by taking into account temporary payment defaults as well. In addition, to our knowledge tax arrears as a type of payment default has so far not been applied in bankruptcy prediction, although their existence has successfully been used as a dependent variable with financial ratios being independent (see Höglund 2017).

\subsection{Research Propositions}

We would argue that as many SMEs do not witness financial problems one year before bankruptcy portrayed through the annual report, but in turn start witnessing temporary liquidity problems, models based on tax arrears are more accurate than models based on financial ratios in the short-run. Further away from bankruptcy, liquidity problems are equally frequent for future bankrupt and non-bankrupt firms, and thus, financial ratio-based models are more beneficial in the long-run. As different types of variables are beneficial in the short- and long-run, their conjoint usage should logically lead to the highest classification accuracy. Relying on the latter theoretical explanations and past achievements in the literature, we phrase three research propositions for the empirical part of the paper, while we consider one specific type of payment defaults, i.e., tax arrears, in this study:

P1: A model based on payment defaults leads to a higher accuracy in bankruptcy prediction than a model based on financial ratios only in the short-run.

P2: The accuracy of a model based on payment defaults decreases further away from bankruptcy.

P3: A model incorporating both payment defaults and financial ratios leads to a higher accuracy than the individual models incorporating these variables. 


\section{Data and Methods}

\subsection{Dataset and General Setting of the Study}

The dataset of this paper includes all Estonian bankrupted firms from 2013-2017, in case of which the following restrictions have been applied. First, all firms must have information available to calculate variables outlined in Sections 3.2 and 3.3. Second, we demand the financial report of a bankrupted firm to be not older than two years from the moment of bankruptcy declaration. With this restriction, we guarantee that the annual report portrays pre-bankruptcy financial situation homogenously for firms included in the analysis and is available for comparative purposes with payment defaults. On average, the financial report in the dataset portrays financial situation one year before bankruptcy declaration. In total, 512 bankrupted firms are included in the analysis, which are all SMEs.

Concerning survived firms, 4003 firms are used which are functional at the time of the analysis. All firms which have financial information available from 2011 to 2015 are chosen, irrespective of how well they perform. The latter is important to avoid a bias of discriminating only in between bankrupt and "successful" survived firms. The time 2011-2015 is determined by the fact that the reports of bankrupted firms originate from the same time interval. In the viewed period, Estonia had recovered from the consequences of the global financial crisis and these years were characterized by stable economic growth. Thus, the viewed period is not subject to any abnormal performance of firms due to economic recession.

For calculating financial ratios of bankrupt firms, we use the last available annual financial report before bankruptcy. In case of survived firms, we calculate the financial ratios for all firms for all five years incorporated to the analysis. In Estonia, firms are responsible for submitting an annual report in maximum six months after the end of the fiscal year, which for the vast majority of firms overlaps with the calendar year.

Concerning taxes, firms need to submit tax reports and pay taxes twice in the month following the month that the taxes were incurred. Specifically, on the 10th day of the month for taxes concerned with salaries and on the 20th day of the month for value added tax. Estonia is among a few countries in the world where profit is not taxed on an accrual basis, but only when dividends are paid. When dividends are paid, the respective income tax is subject to the same principles as salaries. When tax arrears (i.e., unpaid tax debt due) occur, this is observable live on the Estonian Tax and Customs Board database. From the latter database, we have obtained the values of tax arrears for the whole population for each month end in the viewed period of 2011-2017. The usage of the month end is a more suitable option when compared with for instance one day delay of paying taxes. This is because a few days' delays of paying taxes is common in Estonia and are more subject to administrative or diligence reasons, rather than pointing to a temporary liquidity crisis. Thus, tax arrears' information can be used dynamically to view the emergence of problems up to the exact month when bankruptcy occurred. As the annual reports are up to 2 years old, in case of tax arrears data, we consider a 24 month long period before bankruptcy is declared. For survived firms, we use multiple 24 month long periods within the years from 2011 to 2016.

We do not apply other payment defaults (i.e., to private creditors, such as banks and suppliers) in this study for multiple reasons. First, in Estonia no single database incorporates all payment defaults to private creditors. Second, some of such defaults might not be documented, for instance because of their small size or creditors executing their claims in a different way (e.g., suing managers who have guaranteed the credit). Third, such defaults might not be documented precisely in respect to their start or end period, e.g., due to the fact that creditors could be delaying the execution of a claim because of groundless promises by debtors to pay the debt.

To provide an answer in which period tax arrears' information is more useful than financial ratios, we consider different pre-bankruptcy periods concerning tax arrears. The usage of financial information in this study has been consolidated into Table 1. 
Table 1. The logic of calculating financial ratios and variables portraying tax arrears in this study.

\begin{tabular}{cc}
\hline \multicolumn{2}{c}{ Information Sources for Calculating Financial Ratios in This Study } \\
\hline $\begin{array}{c}\text { Bankrupted firms } \\
\text { Survived firms }\end{array}$ & $\begin{array}{c}\text { Last annual report (not older than two years from bankruptcy moment) } \\
\text { All annual reports from } 2011 \text { to } 2015\end{array}$ \\
\hline \multicolumn{2}{c}{ Information sources for calculating tax arrears variables in this study } \\
12 month long periods before bankruptcy, where the respective numbers indicate \\
month x to month y before the bankruptcy declaration month: 1-12, 4-15, 7-18, \\
10-21, 13-24. A single 24 month long period before bankruptcy, where the \\
respective numbers indicate month x to month y before the bankruptcy declaration \\
month: 1-24. \\
12 month long periods are used as six full years from 2011 to 2016. A single 24 \\
month period is used as five two-year periods: 2011-2012, 2012-2013, 2013-2014, \\
2014-2015, 2015-2016. As there are proportionally much less bankruptcies from \\
2017, then in case of survived firms that year is neglected from the analysis.
\end{tabular}

Source: own elaboration.

\subsection{Financial Ratios Portraying Different Domains}

The financial ratios for this study have been chosen based on their previous usage for bankruptcy prediction and taking into account that all important financial ratio domains would be covered (see the formulas and ratio domains in Table 2). Firm leverage is reflected by the total debt to total assets ratio (DA). This ratio in its different forms (e.g., total equity to total assets or total equity to total debt) might be the most common and useful failure predictor. The ratio has a strong intersection with legislation, as business and insolvency codes in different countries often set minimum requirements for firms' equity. Profitability is captured with two ratios, i.e., net income to total assets and net income to operating revenue. The former is a more common profitability ratio in bankruptcy prediction and was used already in the Altman (1968) model, although having EBIT instead of net income in the numerator. Static liquidity is portrayed with two ratios, namely either the quotient of cash minus current liabilities to total assets or the quotient of current assets minus current liabilities to total assets. These ratios have been frequently used in the form of cash to current liabilities (quick ratio) and current assets to current liabilities (current ratio), but the usage of such ratios is problematic. Namely, as among survived firms there might be a fair amount of companies with no or very low level of current liabilities, such ratios would obtain extreme values or the value cannot be calculated at all. Moreover, the division with total assets helps us to have a better overview how large the surplus or deficit of cash or current assets is in comparison to all assets a firm possesses. A firm's cash flow creation is portrayed with two ratios reflecting the quotient of operating cash flow to either operating revenue or total assets. The productivity (efficiency) of a firm's assets is reflected by the quotient of operating revenue to total assets. Finally, the burden of interest paid on debt is proxied with two ratios, specifically the quotient of total financial revenues minus total financial expenses to either total assets or operating revenue. The latter two variables (with similar, but not necessarily identical formulas) have been often classified as solvency (solidity) ratios.

The ten applied financial ratios reflect the most usual domains used in previous bankruptcy prediction studies, i.e., profitability, cash flow creation, leverage, liquidity, solidity, and profitability. We acknowledge that many more financial ratios have been applied in previous studies, but they are mostly very similar (or mere modifications) to the ones used, and thus, would evidently provide only a marginal surplus (if at all) to classification accuracies. In addition, the calculation of very specific financial ratios is altered by the availability of financial information, as the financial reports of SMEs are often quite brief. Because of the latter, we can for instance use the difference of financial revenues and financial expenses, rather than specific types of those revenues/expenses. In case of all applied financial ratios, the general rule is that higher values should reduce the bankruptcy probability on a univariate principle. The exception is DA, where the situation is the reverse. 
Table 2. Financial ratio abbreviations, domains, and formulas used in this study.

\begin{tabular}{|c|c|c|}
\hline Ratio Abbreviation & Domain & Formula \\
\hline CCLA & liquidity & (cash—current liabilities)/total assets \\
\hline CACLA & liquidity & (current assets—current liabilities)/total assets \\
\hline NIA & profitability & net income/total assets \\
\hline NIOR & profitability & net income/operating revenue \\
\hline DA & leverage/solidity & total debt/total assets \\
\hline ORA & productivity & operating revenue/total assets \\
\hline FREOR & interest burden & (financial revenues-financial expenses)/operating revenue \\
\hline FREA & interest burden & (financial revenue-financial expenses)/total assets \\
\hline OCFA & cash flow creation & operating cash flow/total assets \\
\hline OCFOR & cash flow creation & operating cash flow/operating revenue \\
\hline
\end{tabular}

Source: own elaboration.

\subsection{Variables Portraying Tax Arrears}

Unlike with financial ratios, there are no uniform guidelines on how to calculate variables portraying the dynamics and content of tax arrears. Still, past theoretical and empirical research provides hints that larger and/or more frequent payment defaults increase the likelihood of failure. Derived from that logic, both of those dimensions should be incorporated into the analysis. To capture the scale of tax arrears, we calculate the maximum of tax arrears occurring in the viewed period. As large tax arrears can occur only episodically (e.g., only during one month in the sequence of 12 months), we extend the scale variable to incorporate frequency context as well by calculating the median of tax arrears in the viewed period. The frequency of tax arrears is captured by a variable counting the month ends when tax arrears were present. Still, the latter variable might be limited, because tax arrears can occur for instance every second month, i.e., they occur frequently, but still episodically. In order to enhance the frequency analysis by also incorporating the severity of ongoingness of payment defaults, we also introduce a variable measuring the longest sequence of month ends when tax arrears occurred. Thus, the four applied tax arrears' variables (see Table 3) also incorporate both the scale and frequency of payment defaults in a combined manner.

Table 3. Abbreviations and calculation explanations of variables portraying tax arrears in this study.

\begin{tabular}{cc}
\hline Variable Abbreviation & Calculation Explanation \\
\hline TMAX & Maximum tax arrears in the viewed sequence on month ends \\
TMEDIAN & Median tax arrears in the viewed sequence of month ends \\
TCOUNT & Number of month ends with tax arrears in the viewed sequence \\
TCONSMON & Length of the longest sequence of month ends with tax arrears \\
\hline
\end{tabular}

Source: Own elaboration; Note: we consider the presence of tax arrears as over 100 euros unpaid tax debt, as tax authority does not add a disclaimer of owing taxes in case of very small arrears, and also, managers can occasionally forget paying very small tax arrears.

\subsection{Methods}

We apply one classical statistical (i.e., logistic regression, noted as LR) and one machine learning (i.e., multilayer perceptron with two hidden layers, noted as MP) tool for composing the prediction models. In case of using only one method, the results could be biased towards that specific method, and therefore, not generalizable. These two methods are probably the most exploited classical and novel methods in bankruptcy prediction, thus their choice is fairly justified based on the developments in previous research. We acknowledge that there is nowadays a myriad of different methods (especially in the area of machine learning) available for failure prediction. Still, as the first and foremost aim of the paper is to show whether and in what context the information about tax arrears can be exploited in bankruptcy prediction, we find the usage of two methods a sufficient choice. In addition, based on the 
results in the empirical section, we thoroughly explain why the usage of additional methods would probably not have provided a surplus to the obtained results.

In bankruptcy prediction, there are different streams concerning how to use observations in the analysis. The classical studies have used (rather) equal samples for bankrupted and survived firms. This definitely guarantees that the analysis reaches a clear conclusion how accurately bankrupted and survived firms can be discriminated from each other. Still, such selection of survived firms should be avoided, as there is a serious risk of creating a bias, i.e., the sample of survived firms does not represent the population it originates from. Moreover, when for instance a credit analyst is solving a practical classification problem, a firm under consideration originates from the whole population without any preselection. Thus, if available, the population of survived firms should be used irrespective of their characteristics. Therefore, our dataset (see Section 3.1) incorporates all bankrupted firms and all their survived counterparts, for which the respective annual reports were available.

There are different options on how to use LR and MP. When the frequencies in two groups (i.e., bankrupted and non-bankrupted firms) are very imbalanced (which is the usual case and also applies for this study), algorithms can result in classifying a majority group (i.e., non-bankrupt firms) as correctly as possible, at the same time creating (huge) misclassification errors in case of the minority group (i.e., bankrupt firms). Therefore, we administer a procedure frequently used in bankruptcy prediction research (see e.g., Altman et al. 2017) by weighting the two groups of firms to be equal in the analysis. In case of LR, the weights for observations are calculated as 0.5 divided by the share of respective group in the population used. In case of MP, we achieve the same by making synthetic observations. Such a method, i.e., a synthetic minority oversampling technique (SMOTE), has been frequently used in case of machine learning classification applications for bankruptcy prediction (Kim et al. 2015). SMOTE is achieved by repeating the observations of bankrupt firms as long as their population size equals that of non-bankrupt firms. We acknowledge that different weights could be applied in this study, but this is specifically dependent on how large the misclassification costs of (non-)bankrupt firms are (in practice). Likewise with majority of previous studies in the area, we do not incorporate misclassification costs in the analysis.

In order to understand what are the prediction abilities of individual variables, we first provide the results in case of LR by using only single variables from Tables 2 and 3. After that, we conduct three types of analyses: (a) using all financial ratios together for LR and MP, (b) using all tax arrears' variables together for LR and MP, (c) using financial ratios and tax arrears' variables together for LR and MP. When the comparison of (a) and (b) enables us to outline the individual prediction abilities of the specific variables through the two applied methods, then (c) introduces a joint analysis. Results are provided for both test and hold-out samples.

\section{Results and Discussion}

\subsection{Univariate Prediction Abilities of Variables}

We first outline the univariate prediction abilities of the applied variables (see Table 4), while the descriptive statistics of the variables have been provided in Appendix A Tables A1-A3. The results in Table 4 have been presented for descriptive purposes and obtained from LR by applying each variable individually. The most useful financial ratio on a univariate principle is DA, which is a fairly common and useful predictor in previous studies (usually also in the form of total equity to total assets ratio). Still, the accuracy $(77.1 \%)$ of this solidity ratio remains modest, closely followed by a liquidity ratio CCLA with $75.7 \%$ accuracy.

The tax arrears' variables indicate better predictive performance. For instance, when calculated for the period 1-12 months before bankruptcy declaration, all of them outperform DA. When further away from bankruptcy, the individual predictive power of tax arrears' variables deteriorates. For instance, when the period 13-24 months before bankruptcy prediction is applied, the most accurate tax arrears variable is TMAX, indicating that the largest tax arrears in that period obtains the same 
predictive power as DA, i.e., $77.1 \%$. Thus, the univariate results provide an initial indication that tax arrears have remarkable predictive power and this result is further elaborated with multivariate analysis in the next section.

Table 4. Univariate prediction accuracies (\%) of variables.

\begin{tabular}{llll}
\hline \multicolumn{4}{c}{ Financial Ratios } \\
\hline CCLA & 75.7 & ORA & 60.5 \\
CACLA & 70.1 & FREOR & 59.5 \\
NIA & 61.4 & FREA & 63.6 \\
NIOR & 59.5 & OCFA & 49.3 \\
DA & 77.1 & OCFOR & 42.2 \\
\hline \multicolumn{4}{c}{ Tax Arrears Variables } \\
\hline TMAX1-12 & 85.3 & TMAX10-21 & 77.6 \\
TMEDIAN1-12 & 78.5 & TMEDIAN10-21 & 71.5 \\
TCOUNT1-12 & 84.9 & TCOUNT10-21 & 76.3 \\
TCONSMON1-12 & 85.1 & TCONSMON10-21 & 76.9 \\
TMAX4-15 & 82.1 & TMAX13-24 & 77.1 \\
TMEDIAN4-15 & 74.8 & TMEDIAN13-24 & 70.3 \\
TCOUNT4-15 & 81.6 & TCOUNT13-24 & 74.7 \\
TCONSMON4-15 & 81.0 & TCONSMON13-24 & 75.4 \\
TMAX7-18 & 79.3 & TMAX1-24 & 85.9 \\
TMEDIAN7-18 & 73.5 & TMEDIAN1-24 & 74.0 \\
TCOUNT7-18 & 77.9 & TCOUNT1-24 & 83.0 \\
TCONSMON7-18 & 79.0 & TCONSMON1-24 & 83.8 \\
\hline
\end{tabular}

Source: own elaboration; Note: Tx-y indicates tax arrears variable from period month $\mathrm{x}$ to month $\mathrm{y}$ before bankruptcy is declared.

\subsection{Multivariate Approach with Logistic Regression and Multilayer Perceptron}

The classification accuracies of the logistic regression and multilayer perceptron models are quite similar, although the logistic regression models are somewhat more precise on holdout sample when tax arrears' variables are applied. The higher accuracy in case of non-bankrupt firms observable in Table 5 for tax arrears' models can be explained by a simple financial logic. Type I error (i.e., bankrupt firms classified as non-bankrupt) is caused by a certain proportion of bankrupt firms having no tax arrears during the viewed period. The survived firms normally do not witness tax arrears, or at least not in such scale and frequency as the bankrupt firms. Thus, when using tax arrears in bankruptcy prediction, no sophisticated logic about the occurring patterns is necessary, and rather, their existence with a certain frequency and magnitude is a sufficient proof of potential serious financial problems.

The few percentage points superiority of the LR models over the MP models in case of tax arrears' variables could mostly be explained by the MP models overtraining the relationship in between independent and dependent variables, i.e., it is considered to be more sophisticated than it actually is.

The prediction abilities of tax arrears' models gradually decrease when looking at periods further away from bankruptcy declaration. The logistic regression model TA10-21 and the multilayer perceptron model TA7-18 are the first ones being not able to outperform financial ratios in bankruptcy prediction. In case of the LR model, the latter means that when looking at the time before bankruptcy, then at a certain point in between the 7th and 10th month before the bankruptcy declaration, the usage of financial ratios becomes more beneficial than tax arrears' information. Thus, tax arrears' information is especially useful for predictive purposes in the short-run before a firm becomes bankrupt.

We find support for all three research propositions set for this study. Payment defaults' dynamics portrayed by tax arrears can lead to a higher bankruptcy prediction accuracy than financial ratios in the short-run (P1), but that accuracy reduces further away from bankruptcy (P2) and at a certain point is overrun by the accuracy of a model based on financial ratios. In addition, the model incorporating both variable domains leads to the highest accuracy (P3). The prediction accuracy of the financial ratios' 
model is similar to the findings in previous studies (e.g., Altman et al. 2017; du Jardin 2017), while the tax arrears' models obtain higher accuracies than previous models based on payment defaults (e.g., Back 2005; Ciampi et al. 2019). In addition, as suggested by previous studies (e.g., Iwanicz-Drozdowska et al. 2016; Ciampi et al. 2019), a combined model of financial ratios and payment defaults leads to the highest possible accuracy.

Table 5. Prediction accuracies (\%) of composed multivariate models.

\begin{tabular}{|c|c|c|c|c|c|c|c|c|c|}
\hline \multirow{2}{*}{ Variables } & \multicolumn{4}{|c|}{ Logistic Regression } & \multicolumn{5}{|c|}{ Multilayer Perceptron } \\
\hline & $\begin{array}{c}\text { Test } \\
\text { Sample }\end{array}$ & $\begin{array}{l}\text { Holdout } \\
\text { Sample }\end{array}$ & AB & ANB & $\begin{array}{l}\text { Training } \\
\text { Sample }\end{array}$ & $\begin{array}{c}\text { Test } \\
\text { Sample }\end{array}$ & $\begin{array}{l}\text { Holdout } \\
\text { Sample }\end{array}$ & $\mathbf{A B}$ & ANB \\
\hline Financial ratios & 79.9 & 79.5 & 80.4 & 78.7 & 81.8 & 80.6 & 81.9 & 85.4 & 78.4 \\
\hline TA1-12 & 86.9 & 89.5 & 83.3 & 95.7 & 86.8 & 86.9 & 86.7 & 84.6 & 88.9 \\
\hline TA4-15 & 83.6 & 85.2 & 75.5 & 94.9 & 83.5 & 83.9 & 84.7 & 79.7 & 89.8 \\
\hline TA7-18 & 80.4 & 82.1 & 69.6 & 94.5 & 80.2 & 79.8 & 80.6 & 71.9 & 88.9 \\
\hline TA10-21 & 78.9 & 78.6 & 62.8 & 94.5 & 78.2 & 78.8 & 78.5 & 68.0 & 89.0 \\
\hline TA13-24 & 77.4 & 78.0 & 61.8 & 94.2 & 78.1 & 78.0 & 77.8 & 67.1 & 88.4 \\
\hline TA1-24 & 86.7 & 89.9 & 84.3 & 95.4 & 86.8 & 86.5 & 86.7 & 88.6 & 84.9 \\
\hline $\begin{array}{c}\text { Financial ratios } \\
\text { and TA1-24 } \\
\text { combined }\end{array}$ & 90.2 & 91.3 & 89.2 & 93.4 & 87.7 & 87.6 & 87.5 & 90.8 & 84.3 \\
\hline
\end{tabular}

Source: Own elaboration; Note: TAx-y means tax arrears variables' model from period month $\mathrm{x}$ to month $\mathrm{y}$ before bankruptcy is declared. $\mathrm{AB}$ and $\mathrm{ANB}$ refer respectively to accuracies among bankrupt and non-bankrupt firms in the hold-out sample.

\subsection{Theoretical Implications}

The main theoretical implication from the study is that the dynamics of payment defaults can be very useful as a bankruptcy predictor shortly before bankruptcy. In addition, the finding complements previous studies (see Section 2.3) applying different types of payment defaults in a more simple manner. While tax arrears as a type of payment default have not been applied in previous studies, this study showed that they have remarkable value in bankruptcy prediction. Finally, we agree with the previous studies suggesting that variables other than financial ratios should be applied in SME failure prediction, but with a substantial extension. Namely, the individual usage of such variables could lead to a better predictive performance of models in the short-run or these variables could be used conjointly with other variables, such as financial ratios, in the long-run.

\subsection{Practical Implications}

This study provides multiple guidelines for various stakeholders, such as builders of insolvency prediction models, lenders (e.g., banks or trade credit providers), or credit information bureaus.

First, when used dynamically, past temporary payment defaults can include valuable individual and incremental information when aiming to build more accurate bankruptcy prediction models. In this respect, both the size and duration of payment defaults can matter.

Second, financial ratios are not very useful in predicting future bankruptcy, as when implementing models based on them for SMEs in practice, it is difficult to achieve accuracy levels that would avoid substantial losses for creditors.

Third, and maybe the most substantial practical implication, the usage of payment defaults is a vital substitution when annual reports of firms are not available in time or at all. Payment defaults are usually available on a live principle, as they are submitted by creditors, not by the firm itself.

\subsection{Limitations}

There are several limitations of this study that should be acknowledged. First, this study focused on a specific type of payment defaults, i.e., tax debt not paid when due, in one country. The tax laws and their practical application, i.e., enforcing tax claims by the relevant authority, can vary through 
different countries. Thus, when replicating the ideas proposed in this article in other environments, the country-specific tax laws and practice of dealing with tax arrears is of high essence.

Second, using payment defaults to other stakeholders, such as banks, trade credit providers, or employees could even enhance the prediction abilities. The incorporation of this information has proven to be valuable in previous relevant studies (e.g., Wilson and Altanlar 2014; Ciampi et al. 2019). Due to the variation in firms' business models, tax arrears might emerge not at all before bankruptcy, but other payment defaults might in turn be present.

Third, although tax arrears are not remarkably subject to the information disclosure issue compared to financial ratios, they are not fully free from it. Namely, some firms might engage in illegal practices, e.g., not submit tax declarations at all or provide false information in them.

\section{Conclusions}

This study aimed to compare the usefulness of tax arrears and financial ratios in bankruptcy prediction. The models created indicate that shortly before bankruptcy, tax arrears' models outrun the financial ratio-based models in terms of accuracy. Still, this accuracy reduces when further periods before bankruptcy declaration are considered. The highest accuracy is obtained by using tax arrears and financial ratios simultaneously.

The study provides important implications for the relevant research area. It indicates that the dynamic usage of only a certain type of payment defaults, i.e., tax arrears, can substantially outrun the accuracies of financial ratio-based models. Thus, despite the availability of hundreds of financial ratio-based prediction models, future researchers should pay more attention to payment default variables, which incorporate substantial possibilities to increase prediction accuracies.

This study can be extended in different ways. The main extension includes relaxing the previously outlined limitations, for instance by including different types of payment defaults. In addition, tax arrears' information could be supplemented by information about the tax payment behavior of firms, as during the retrenchment of activities in the decline process, small tax arrears could have a more important role than in usual circumstances. It is important to test the usefulness of tax arrears in bankruptcy prediction in other countries as well when such information is available. Last but not least, there might be potential to enhance the prediction accuracies by including variables about the background of managers, for instance concerning their past risk behavior in other firms.

Author Contributions: Both authors contributed to all parts.

Funding: This research was funded by the Estonian Ministry of Education and Research grant number IUT20-49. The first author acknowledges support from University of Tartu Foundation's Ernst Jaakson Commemorative Scholarship.

Conflicts of Interest: The authors declare no conflict of interest.

\section{Appendix A}

Table A1. Descriptive statistics of financial ratios.

\begin{tabular}{|c|c|c|c|c|c|c|c|c|c|c|c|}
\hline Status & $\begin{array}{l}\text { Descriptive } \\
\text { Statistic }\end{array}$ & CCLA & CACLA & NIA & NIOR & DA & ORA & FREOR & FREA & OCFA & OCFOR \\
\hline \multirow{6}{*}{ NB } & $\mathrm{N}$ & \multicolumn{10}{|c|}{20,015} \\
\hline & Mean & 0.07 & 0.43 & 0.07 & 0.04 & 0.35 & 2.00 & 0.00 & 0.00 & 0.10 & 0.09 \\
\hline & $\begin{array}{c}\text { Std. } \\
\text { Deviation }\end{array}$ & 0.49 & 0.42 & 0.26 & 0.36 & 0.31 & 2.06 & 0.03 & 0.01 & 0.27 & 0.33 \\
\hline & Median & 0.03 & 0.47 & 0.05 & 0.03 & 0.26 & 1.33 & 0.00 & 0.00 & 0.07 & 0.06 \\
\hline & Minimum & -0.95 & -0.65 & -0.74 & -1.30 & 0.00 & 0.03 & -0.10 & -0.04 & -0.62 & -0.92 \\
\hline & Maximum & 0.96 & 1.00 & 0.65 & 0.79 & 1.12 & 8.92 & 0.09 & 0.04 & 0.74 & 0.88 \\
\hline
\end{tabular}


Table A1. Cont.

\begin{tabular}{cccccccccccc}
\hline Status & $\begin{array}{c}\text { Descriptive } \\
\text { Statistic }\end{array}$ & CCLA & CACLA & NIA & NIOR & DA & ORA & FREOR & FREA & OCFA & OCFOR \\
\hline \multirow{6}{*}{ N } & & & & & & & 512 & & & & \\
& Mean & -0.79 & -0.24 & -0.31 & -0.09 & 1.09 & 4.00 & 0.01 & 0.01 & 0.24 & 0.16 \\
B & $\begin{array}{c}\text { Std. } \\
\text { Deviation } \\
\text { Median }\end{array}$ & 0.99 & 1.00 & 1.03 & 0.32 & 1.10 & 5.18 & 0.03 & 0.03 & 1.25 & 0.78 \\
& -0.62 & 0.01 & -0.01 & 0.00 & 0.87 & 2.39 & 0.00 & 0.00 & 0.04 & 0.01 \\
& Minimum & -5.42 & -5.08 & -5.26 & -1.48 & 0.12 & 0.19 & -0.04 & -0.07 & -2.33 & -0.83 \\
& Maximum & 0.27 & 0.80 & 0.57 & 0.31 & 6.29 & 27.57 & 0.11 & 0.10 & 5.58 & 3.60 \\
\hline$p$-value of ANOVA & 0.000 & 0.000 & 0.000 & 0.000 & 0.000 & 0.000 & 0.000 & 0.000 & 0.016 & 0.044 \\
\hline
\end{tabular}

Source: own elaboration. Note: B-bankrupt, NB-non-bankrupt. For non-bankrupt firms, the population size 20,015 originates from using data from 5 years (2011-2015) for 4003 firms (see Section 3.1 for more information).

Table A2. Descriptive statistics of tax arrears variables (part 1).

\begin{tabular}{|c|c|c|c|c|c|c|c|c|c|c|c|c|c|}
\hline$\frac{D}{\tilde{J}}$ & 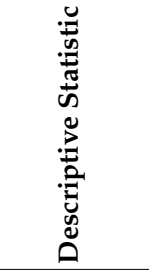 & 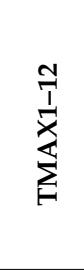 & 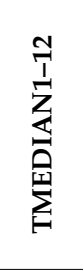 & 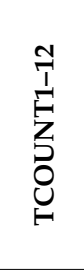 & 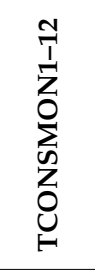 & 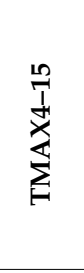 & 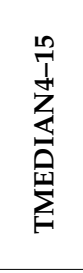 & 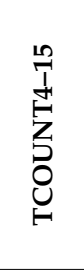 & 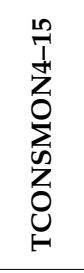 & 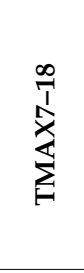 & 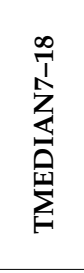 & 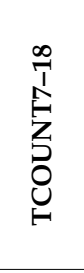 & 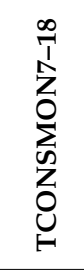 \\
\hline \multirow{6}{*}{ NB } & $\mathrm{N}$ & \multicolumn{12}{|c|}{24,018} \\
\hline & Mean & 0.4 & 0.1 & 0.5 & 0.4 & 0.4 & 0.1 & 0.5 & 0.4 & 0.4 & 0.1 & 0.5 & 0.4 \\
\hline & Std. Dev. & 3.8 & 1.7 & 1.8 & 1.6 & 3.8 & 1.7 & 1.8 & 1.6 & 3.8 & 1.7 & 1.8 & 1.6 \\
\hline & Median & 0 & 0 & 0 & 0 & 0 & 0 & 0 & 0 & 0 & 0 & 0 & 0 \\
\hline & Min. & 0 & 0 & 0 & 0 & 0 & 0 & 0 & 0 & 0 & 0 & 0 & 0 \\
\hline & Max. & 187 & 125 & 12 & 12 & 187 & 125 & 12 & 12 & 187 & 125 & 12 & 12 \\
\hline \multirow{6}{*}{ B } & $\mathrm{N}$ & \multicolumn{12}{|c|}{512} \\
\hline & Mean & 59.1 & 36.9 & 7.4 & 7.1 & 48.9 & 29.8 & 6.8 & 6.3 & 41.5 & 23.9 & 6.2 & 5.7 \\
\hline & Std. Dev. & 171.5 & 145.0 & 4.7 & 4.8 & 163.3 & 128.7 & 5.0 & 5.0 & 150.8 & 91.4 & 5.1 & 5.1 \\
\hline & Median & 13.7 & 3.5 & 9.0 & 8.0 & 9.7 & 1.2 & 8.0 & 6.0 & 6.4 & 0.7 & 7.0 & 5.0 \\
\hline & Min. & 0 & 0 & 0 & 0 & 0 & 0 & 0 & 0 & 0 & 0 & 0 & 0 \\
\hline & Max. & 2427 & 2396 & 12 & 12 & 2427 & 2396 & 12 & 12 & 2427 & 1462 & 12 & 12 \\
\hline \multicolumn{2}{|c|}{$\begin{array}{c}p \text {-value of ANOVA } \\
\text { Welch test }\end{array}$} & 0.000 & 0.000 & 0.000 & 0.000 & 0.000 & 0.000 & 0.000 & 0.000 & 0.000 & 0.000 & 0.000 & 0.000 \\
\hline
\end{tabular}

Source: own elaboration. Note: B-bankrupt, NB-non-bankrupt. Mean, median and std. deviation presented in thousands euros for TMAX and TMEDIAN. For non-bankrupt firms, the population size 24,018 originates from using 6 years (2011-2016) for 4003 firms (see Section 3.1 for more information).

Table A3. Descriptive statistics of tax arrears variables (part 2).

\begin{tabular}{|c|c|c|c|c|c|c|c|c|c|c|c|c|c|}
\hline $\begin{array}{l}\frac{n}{ \pm ̃ n} \\
\text { के }\end{array}$ & 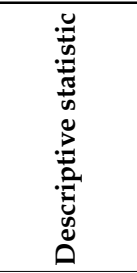 & 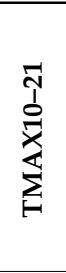 & 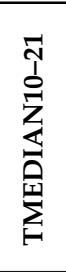 & 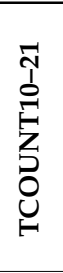 & 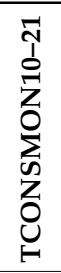 & 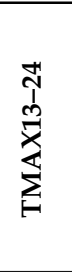 & 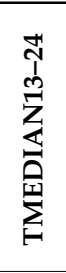 & 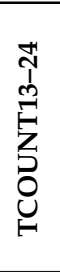 & 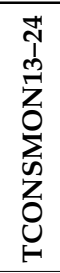 & $\begin{array}{l}\stackrel{\Delta}{N} \\
\stackrel{1}{x} \\
\sum_{i}^{\mid}\end{array}$ & 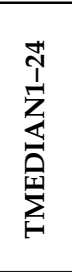 & 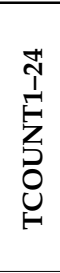 & 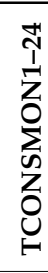 \\
\hline \multirow{6}{*}{ NB } & $\mathrm{N}$ & \multicolumn{12}{|c|}{24,018} \\
\hline & Mean & 0.4 & 0.1 & 0.5 & 0.4 & 0.4 & 0.1 & 0.5 & 0.4 & 0.6 & 0.1 & 0.9 & 0.6 \\
\hline & Std. Dev. & 3.8 & 1.7 & 1.8 & 1.6 & 3.8 & 1.7 & 1.8 & 1.6 & 4.6 & 1.3 & 3.4 & 2.6 \\
\hline & Median & 0 & 0 & 0 & 0 & 0 & 0 & 0 & 0 & 0 & 0 & 0 & 0 \\
\hline & Min. & 0 & 0 & 0 & 0 & 0 & 0 & 0 & 0 & 0 & 0 & 0 & 0 \\
\hline & Max. & 187 & 125 & 12 & 12 & 187 & 125 & 12 & 12 & 187 & 109 & 24 & 24 \\
\hline
\end{tabular}


Table A3. Cont.

\begin{tabular}{|c|c|c|c|c|c|c|c|c|c|c|c|c|c|}
\hline$\underbrace{2}_{\vec{t}}$ & 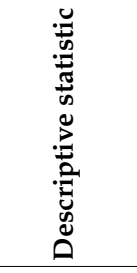 & 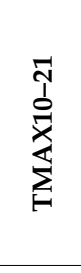 & 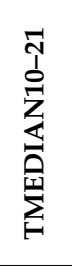 & 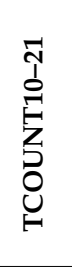 & 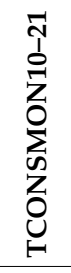 & 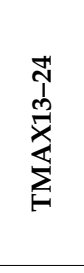 & 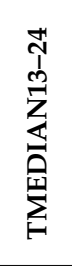 & 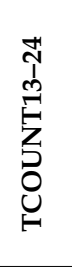 & 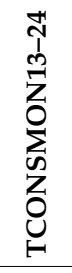 & 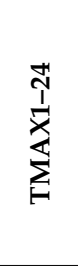 & 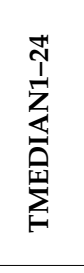 & 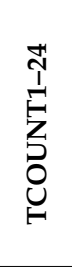 & 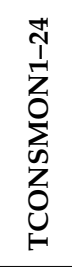 \\
\hline \multirow{6}{*}{ B } & $\mathrm{N}$ & \multicolumn{12}{|c|}{512} \\
\hline & Mean & 38.5 & 18.6 & 5.7 & 5.3 & 32.3 & 17.7 & 5.3 & 4.8 & 64.1 & 23.2 & 12.7 & 11.2 \\
\hline & Std. Dev. & 157.6 & 61.9 & 5.1 & 5.0 & 127.7 & 64.6 & 5.1 & 4.9 & 190.4 & 90.0 & 9.0 & 8.8 \\
\hline & Median & 4.9 & 0 & 5.0 & 4.0 & 3.6 & 0 & 3.5 & 3.0 & 15.6 & 0.7 & 13.0 & 9.0 \\
\hline & Min. & 0 & 0 & 0 & 0 & 0 & 0 & 0 & 0 & 0 & 0 & 0 & 0 \\
\hline & Max. & 2427 & 872 & 12 & 12 & 1932 & 872 & 12 & 12 & 2427 & 1462 & 24 & 24 \\
\hline & $\begin{array}{l}\text { ANOVA } \\
\text { test }\end{array}$ & 0.000 & 0.000 & 0.000 & 0.000 & 0.000 & 0.000 & 0.000 & 0.000 & 0.000 & 0.000 & 0.000 & 0.000 \\
\hline
\end{tabular}

Source: own elaboration. Note: B—bankrupt, NB—non-bankrupt. Mean, median and std. deviation presented in thousands euros for TMAX and TMEDIAN. For non-bankrupt firms, the population size 24,018 originates from using 6 years (2011-2016) for 4003 firms, while for variables depicting 24 months (ending with "1-24") there are 5 periods used, resulting in 20,015 observations (see Section 3.1 for more information).

\section{References}

Alaka, Hafiz A., Lukumon O. Oyedele, Hakeem A. Owolabi, Vikas Kumar, Saheed O. Ajayi, Olugbenga O. Akinade, and Muhammad Bilal. 2018. Systematic review of bankruptcy prediction models: Towards a framework for tool selection. Expert Systems with Applications 94: 164-84. [CrossRef]

Altman, Edward I. 1968. Financial ratios, discriminant analysis and the prediction of corporate bankruptcy. Journal of Finance 23: 589-609. [CrossRef]

Altman, Edward I., Małgorzata Iwanicz-Drozdowska, Erkki K. Laitinen, and Arto Suvas. 2017. Financial distress prediction in an international context: A review and empirical analysis of Altman's Z-Score model. Journal of International Financial Management $\mathcal{E}$ Accounting 28: 131-71. [CrossRef]

Altman, Edward I., Gabriele Sabato, and Nick Wilson. 2010. The value of non-financial information in SME risk management. The Journal of Credit Risk 6: 95-127. [CrossRef]

Amankwah-Amoah, Joseph. 2016. An integrative process model of organisational failure. Journal of Business Research 69: 3388-97. [CrossRef]

Back, Peter. 2005. Explaining financial difficulties based on previous payment behavior, management background variables and financial ratios. European Accounting Review 14: 839-68. [CrossRef]

Beaver, William H. 1966. Financial ratios as predictors of failure. Journal of Accounting Research 4: 71-111. [CrossRef]

Ciampi, Francesco. 2015. Corporate governance characteristics and default prediction modeling for small enterprises. An empirical analysis of Italian firms. Journal of Business Research 68: 1012-25. [CrossRef]

Ciampi, Francesco, Valentina Cillo, and Fabio Fiano. 2019. Combining Kohonen maps and prior payment behavior for small enterprise default prediction. Small Business Economics. in press. [CrossRef]

Clatworthy, Mark A., and Michael J. Peel. 2016. The timeliness of UK private company financial reporting: Regulatory and economic influences. The British Accounting Review 48: 297-315. [CrossRef]

Crutzen, Nathalie, and Didier van Caillie. 2008. The business failure process. An integrative model of the literature. Review of Business and Economics 53: 287-316.

Dimitras, Augustinos I., Stelios H. Zanakis, and Constantin Zopounidis. 1996. A survey of business failures with an emphasis on prediction methods and industrial applications. European Journal of Operational Research 90: 487-513. [CrossRef]

du Jardin, Philippe. 2015. Bankruptcy prediction using terminal failure processes. European Journal of Operational Research 242: 286-303. [CrossRef]

du Jardin, Philippe. 2017. Dynamics of firm financial evolution and bankruptcy prediction. Expert Systems with Applications 75: 25-43. [CrossRef]

du Jardin, Philippe. 2018. Failure pattern-based ensembles applied to bankruptcy forecasting. Decision Support Systems 107: 64-77. [CrossRef] 
Höglund, Henrik. 2017. Tax payment default prediction using genetic algorithm-based variable selection. Expert Systems with Applications 88: 368-75. [CrossRef]

Iwanicz-Drozdowska, Małgorzata, Erkki K. Laitinen, Arto Suvas, and Edward I. Altman. 2016. Financial and nonfinancial variables as long-horizon predictors of bankruptcy. Journal of Credit Risk 12: 49-78. [CrossRef]

Kim, Myoung-Jong, Dae-Ki Kang, and Hong Bae Kim. 2015. Geometric mean based boosting algorithm with over-sampling to resolve data imbalance problem for bankruptcy prediction. Expert Systems with Applications 42: 1074-82. [CrossRef]

Laitinen, Erkki K. 1999. Predicting a corporate credit analyst's risk estimate by logistic and linear models. International Review of Financial Analysis 8: 97-121. [CrossRef]

Laitinen, Erkki K., and Arto Suvas. 2013. International applicability of corporate failure risk models based on financial statement information: Comparisons across European countries. Journal of Finance E Economics 1: 1-26. [CrossRef]

Liang, Deron, Chia-Chi Lu, Chih-Fong Tsai, and Guan-An Shih. 2016. Financial ratios and corporate governance indicators in bankruptcy prediction: A comprehensive study. European Journal of Operational Research 252: 561-72. [CrossRef]

Lukason, Oliver. 2013. Firm bankruptcies and violations of law: An analysis of different offences. In Dishonesty in Management: Manifestations and Consequences. Edited by Tiia Vissak and Maaja Vadi. Bingley: Emerald, pp. 127-46.

Lukason, Oliver, and Maria-del-Mar Camacho-Miñano. 2019. Bankruptcy risk, its financial determinants and reporting delays: Do managers have anything to hide? Risks 7: 77. [CrossRef]

Lukason, Oliver, and Erkki K. Laitinen. 2019. Firm failure processes and components of failure risk: An analysis of European bankrupt firms. Journal of Business Research 98: 380-90. [CrossRef]

Lukason, Oliver, Erkki K. Laitinen, and Arto Suvas. 2016. Failure processes of young manufacturing micro firms in Europe. Management Decision 54: 1966-85. [CrossRef]

Lussier, Robert N. 1995. A Nonfinancial business success versus failure prediction model for young firms. Journal of Small Business Management 33: 8-20.

Luypaert, Mathieu, Tom Van Caneghem, and Steve Van Uytbergen. 2016. Financial statement filing lags: An empirical analysis among small firms. International Small Business Journal 34: 506-31. [CrossRef]

Munoz-Izquierdo, Nora, Maria Jesus Segovia-Vargas, Maria-del-Mar Camacho-Minano, and David Pasqual-Ezama. 2019. Explaining the causes of business failures using audit report disclosures. Journal of Business Research 98 : 403-14. [CrossRef]

Ohlson, James A. 1980. Financial ratios and the probabilistic prediction of bankruptcy. Journal of Accounting Research 18: 109-31. [CrossRef]

Ooghe, Hubert, and Sofie de Prijcker. 2008. Failure processes and causes of company bankruptcy: A typology. Management Decision 46: 223-42. [CrossRef]

Ravi Kumar, Puvvala, and Vadlamani Ravi. 2007. Bankruptcy prediction in banks and firms via statistical and intelligent techniques-A review. European Journal of Operational Research 180: 1-28. [CrossRef]

Scott, James. 1981. The probability of bankruptcy: A comparison of empirical predictions and theoretical models. Journal of Banking and Finance 5: 317-44.

Sun, Jie, Hui Li, Qing-Hua Huang, and Kai-Yu He. 2014. Predicting financial distress and corporate failure: A review from the state-of-the-art definitions, modeling, sampling, and featuring approaches. Knowledge-Based Systems 57: 41-56. [CrossRef]

Uhrig-Homburg, Marliese. 2005. Cash-flow shortage as an endogenous bankruptcy reason. Journal of Banking $\mathcal{E}$ Finance 29: 1509-34. [CrossRef]

Weitzel, William, and Ellen Jonsson. 1989. Decline in organizations: A literature integration and extension. Administrative Science Quarterly 34: 91-109. [CrossRef]

Wilson, Nick, and Ali Altanlar. 2014. Company failure prediction with limited information: Newly incorporated companies. Journal of the Operational Research Society 65: 252-64. [CrossRef]

(C) 2019 by the authors. Licensee MDPI, Basel, Switzerland. This article is an open access article distributed under the terms and conditions of the Creative Commons Attribution (CC BY) license (http://creativecommons.org/licenses/by/4.0/). 